\title{
PENGARUH PRIMING PADA VIGOR BENIH KEDELAI (Glycine max [L] Merrill) YANG DIKECAMBAHKAN PADA TANAH MASAM
}

\author{
The Effect of Primming on Germination of Soybean (Glycine max. [L] Merrill) \\ Seed Vigor on Ultisol Soil \\ Nabila Lutfiah $^{1}$, Agustiansyah ${ }^{1 *}$, Paul Benyamin Timotiwu' ${ }^{1}$ \\ ${ }^{1}$ Jurusan Agronomi dan Hortikultura, Fakultas Pertanian, Universitas Lampung \\ Jl. Sumantri Brojonegoro No 1 Gedung Meneng, Bandar Lampung 35145 \\ *E-mail korespondensi: agustiansyah.1972@fp.unila.ac.id
}

\begin{abstract}
ABSTRAK
Kebutuhan kedelai (Glycine max L. Merril) terus meningkat seiring dengan pertambahan jumlah penduduk. Perkecambahan kedelai yang disemai pada tanah masam seperti tanah ultisol sering mengalami hambatan. Salah satu cara yang dapat digunakan untuk memperbaiki perkecambahan benih pada tanah masam adalah dengan memberikan perlakuan priming pada benih. Penelitian dilakukan di Rumah Kaca Laboratorium Lapang Terpadu, Fakultas Pertanian, Universitas Lampung yang dilaksanakan pada Desember 2020 sampai dengan Maret 2021. Percobaan ini merupakan percobaan faktorial menggunakan Rancangan Acak Lengkap (RAL) dan diulang tiga kali, dan dilakukan uji lanjut Beda Nyata Jujur dengan taraf kepercayaan 5\%. Analisis data menggunakan program statistika Rstudio. Faktor pertama adalah perlakuan priming, yang terdiri dari kontrol/tanpa priming, priming air $12 \mathrm{jam}$, $\mathrm{KNO}_{3} 1 \% 6 \mathrm{jam}, \mathrm{KNO}_{3} 2 \% 6 \mathrm{jam}, \mathrm{GA}_{3} 50 \mathrm{ppm} 14 \mathrm{jam}, \mathrm{GA}_{3} 100 \mathrm{ppm} 14$ jam, dan PEG 7,5\% $24 \mathrm{jam}$. Faktor kedua adalah 3 benih kedelai varietas Anjasmoro, Burangrang, dan Grobogan. Hasil penelitian menunjukkan bahwa priming Giberelin 50 ppm 14 jam merupakan priming terbaik dalam variabel waktu munculnya kecambah, T50\%, dan kecepatan perkecambahan yang dikecambahkan pada tanah ultisol. Benih kedelai varietas Burangrang menunjukkan T50\% dan jumlah radikula yang muncul pada hari pertama yang terbaik. Benih kedelai varietas Anjasmoro menunjukkan respon terbaik dalam variabel berat kering kecambah normal dan panjang hipokotil kecambah normal pada tanah ultisol.
\end{abstract}

Kata kunci: Kedelai, priming, ultisol, varietas

\begin{abstract}
The need of soybeans continuously increases due to the increasing of human population. The germination of soybeans seeds in the acid soil such as ultisol soil often experienced barrier. One of the ways to improve seed germination in the acid soils is to give priming treatment on the seeds. The research was conducted in the green house of the Integrated Field Laboratory, Faculty of Agriculture, the University of Lampung. It was conducted from December 2020 to March 2021. The research used factorial treatment that was applied in the Completely Random Design with three replicates. The Tukey's Honestly Significance Difference with 5\% level of significance was used to compare the average of treaments. Data analyzing was done by using $R$ studio statistics program. The first factor was kinds of priming which consisted of without priming as a controle, water priming within 12 hours, $\mathrm{KNO}_{3} 1 \%$ within 3 hours, $\mathrm{KNO}_{3} 2 \%$ within 6 hours, GA 50 ppm within 14 hours, GA 100 ppm within 14 hours, and PEG 7,5\% within 24 hours. The second factor was three soybean seed varieties, i.e. Anjasmoro, Burangrang, and Grobogan. Results showed that Giberelin priming of 50 ppm for 14 hours was the best priming in seedling emergence in the ultisol soils. The Burangrang soybean seeds showed the best T50\% and the number of radicles appeared in the first day. The Anjasmoro soybean seeds showed the best response in the dry weight of normal seedling and hypocotyls lenght of normal seedling in the ultisol soils.
\end{abstract}

Key words : Priming, soybean, ultisol, variety 


\section{PENDAHULUAN}

Kebutuhan kedelai (Glycine $\max$ L. Merril) terus meningkat seiring dengan pertambahan jumlah penduduk dan peningkatan industri pangan masyarakat berbahan baku kedelai. Hal ini dikarenakan kedelai merupakan bahan makan pokok masyarakat Indonesia yang digunakan sebagai bahan olahan pembuatan tempe, tahu, dan kecap. Menurut Badan Pusat Statistika (2018) produktivitas kedelai di Lampung pada tahun 2018 sebesar 13,31 $\mathrm{ku} / \mathrm{ha}$ sedangkan produktivitas di Indonesia sebesar 14,44 ku/ha. Menurut Balai Penelitian Tanaman Aneka Kacang dan Umbi (2016) potensi hasil kedelai adalah \pm 3,40 ton/ha.

Sebagian kondisi tanah di Lampung tergolong tanah ultisol yang bereaksi masam dengan $\mathrm{pH}$ berkisar 4,6 - 6,0 (Supriatin et al., 2017). Menurut Prasetyo \& Suriadikarta (2006) tanah ultisol memiliki unsur hara yang rendah, $\mathrm{pH}$ rendah, dan kandungan organik yang rendah. Gejala dari keracunan Al adalah sistem perakaran yang tidak berkembang (pendek dan tebal) akibat penghambatan perpanjangan sel. Ciri utama keracunan $\mathrm{Al}$ adalah terjadi penghambatan pertumbuhan akar, yang pada akhirnya akan menurunkan produktifitas tanaman (Kochian et al., 2004). Kandungan Al yang tinggi mengakibatkan akar tidak efisien dalam menyerap unsur hara dan air (Milatuzzahroh et al., 2019). Kondisi tanah tersebut dapat menghambat perkecambahan benih saat disemai di lapang.

Salah satu cara yang dapat digunakan untuk memperbaiki dan meningkatkan perkecambahan kedelai pada kondisi lahan seperti di atas yaitu dengan perlakuan teknik priming. Priming adalah perlakuan pada benih yang akan mempersiapkan proses metabolisme benih akan aktif tanpa terjadinya perkecambahan. Perlakuan priming dapat meningkatkan perkecambahan, mempercepat waktu kemunculan bibit dan meningkatkan pembentukan tegakan (Nawaz et al., 2013). Terdapat beberapa macam priming yaitu hydro priming, halo priming, osmo priming, dan hormonal priming. Hydro priming adalah perendaman benih pada air sebelum dikecambahkan. Halo priming mengacu pada perendaman benih dalam larutan garam anorganik yaitu $\mathrm{NaCl}, \mathrm{KNO}_{3} \mathrm{CaCl}_{2}, \mathrm{CaSO}_{4}$, dll. Osmo priming adalah perlakuan benih yang direndam dalam larutan gula, Polyethilen Glycol (PEG), gliserol, sorbitol, atau manitol.

Keberhasilan priming dalam memperbaiki perkecambahan benih telah dilaporkan pada benih kedelai (Langeroodi and Noora, 2017), gandum (Putra \& Kurnia, 2019), barley (Jocković et al., 2018), mentimun (Anwar et al., 2020), dan jagung (Prasetyo \& , Arifin Noor Sugiharto, 2019). Tujuan penelitian ini adalah untuk mengetahui pengaruh priming pada perkecambahan benih kedelai yang dikecambahkan pada tanah ultisol.

\section{METODE PENELITIAN}

Penelitian dilakukan di Rumah Kaca Laboratorium Lapang Terpadu, Fakultas Pertanian, Universitas Lampung. Dilaksanakan mulai dari Desember 2020 sampai dengan Maret 2021.

Percobaan ini merupakan percobaan faktorial. Percobaan disusun menggunkaan Rancangan Acak Lengkap (RAL) yang diulang sebanyak tiga kali, dan dilakukan uji lanjut Beda Nyata Jujur dengan taraf kepercayaan $5 \%$. Data yang didapatkan selanjutnya dianalisis menggunakan program statistika Rstudio.

Faktor pertama adalah perlakuan priming, yang terdiri dari kontrol/tanpa priming, priming air $12 \mathrm{jam}, \mathrm{KNO}_{3} 1 \% 6$ jam, $\mathrm{KNO}_{3} 2 \% 6 \mathrm{jam}, \mathrm{GA}_{3} 50 \mathrm{ppm} 14$ jam, $\mathrm{GA}_{3} 100$ ppm 14 jam, dan PEG 7,5 \% 24 jam. Faktor kedua adalah 3 benih kedelai varietas Anjasmoro, Burangrang, dan Grobogan. Didapatkan kombinasi perlakuan (7 perlakuan priming $\times 3$ benih kedelai $=21$ 
perlakuan) yang diulang sebanyak 3 kali, sehingga satuan percobaannya menjadi 63 satuan percobaan. Dalam 1 ulangan dikecambahkan benih kedelai sebanyak 25 butir pada tanah ultisol.

Benih kedelai Anjasmoro, Burangrang, dan Grobogan didapatkan dari Balai Penelitian Aneka Tanaman Kacang dan Umbi (Balitkabi). Sedangkan tanah ultisol didapatkan dari Kebun Percobaan Taman Bogo, Kementerian Pertanian Indonesia yang berlokasi di Kec. Purbolinggo, Lampung Timur. Tanah ultisol tersebut memiliki pH 4.6.

Perlakuan priming $\mathrm{KNO}_{3} 1 \%$ dan $\mathrm{KNO}_{3} \quad 2 \quad \%$ menggunakan metode (Miladinov et al., 2018). Priming $\mathrm{GA}_{3} 50$ ppm dan $\mathrm{GA}_{3} 100$ ppm menggunakan metode (Langeroodi \& Noora, 2017). Serta priming PEG 7,5\% menggunakan metode (Ernita dan F. Mairizki, 2019).

Aplikasi priming dilakukan dengan merendam benih kedelai dalam larutan priming dengan lama perendaman sesuai dengan perlakuan. Priming PEG 7,5\% direndam lebih dahulu, kemudian $\mathrm{GA}_{3} 50$ dan 100 ppm, diikuti air, dan $\mathrm{KNO}_{3} 1$ dan 2 $\%$, agar didapatkan waktu tanam yang bersamaan. Setelah itu benih dikering anginkankan/dilembabkan dan kemudian dilakukan penanaman menggunakan pot tray tipe 128. Dalam 1 ulangan Dilakukan pengamatan setiap hari selama 14 hari.

Variabel pengamatan pada penelitian ini adalah waktu munculnya kecambah (hari) yang diamati pada hari keberapa kotiledon pertama kali muncul kepermukaan tanah. Pengamatan jumlah kecambah pada hari pertama (\%) dilakukan dengan menghitung jumlah kotiledon yang muncul pada hari pertama. Waktu kecambah $50 \%$ (hari) dilakukan pengamatan pada hari keberapa benih sudah berkecambah sebanyak 50\%. Pengamatan kecepatan perkecambahan $(\% /$ hari $)$ dilakukan setiap hari pada hari ke-1 sampai ke-14 untuk mengetahui kecepatan perkecambahan perharinya.

Daya berkecambah (\%) diamati pada hari ke 5 dan 14 dengan menghitung persen kecambah normal yang didapatkan. Berat Kering Kecambah Normal (BKKN) (g) dilakukan pada hari ke-14 dengan mengoven kecambah normal tiap perlakuan pada suhu $80^{\circ} \mathrm{C}$ selama $3 \times 24$ jam dan kemudian ditimbang BKKN menggunakan timbangan digital. Panjang Hipokotil Kecambah Normal (PHKN) $(\mathrm{cm})$ diamati pada hari ke14 dengan mengukur hipokotil kecambah normal mulai dari pangkal hipokotil hingga kotiledon menggunakan milimeter blok. Pengamtan Panjang Radikula Kecambah Normal $(\mathrm{PRKN})(\mathrm{cm})$ dilakukan pada hari ke-14 menggunakan milimeterblok dengan mengukur radikula kecambah normal kedelai mulai dari ujung munculnya radikula hingga pangkal radikula.

\section{HASIL DAN PEMBAHASAN}

Berdasarkan hasil penelitian diperoleh bahwa priming berpengaruh nyata pada waktu kecambah 50\% (T50), daya berkecambah (\%), Berat Kering Kecambah Normal (g), dan Panjang Hipokotil Kecambah Normal (cm). Varietas berpengaruh nyata pada jumlah kecambah pada hari pertama (\%), waktu kecambah $50 \%$ (T50 \%), Berat Kering Kecambah Normal (g), dan Panjang Hipokotil Kecambah Normal $(\mathrm{cm})$ serta tidak terdapat interaksi priming dan varietas (Tabel 1). 
Tabel 1. Rekapitulasi hasil analisis ragam pengaruh priming dan varietas pada variabel perkecambahan benih kedelai yang dikecambahkan pada tanah ultisol

\begin{tabular}{lccc}
\hline Variabel & $\mathrm{P}$ & $\mathrm{V}$ & $\mathrm{P} \times \mathrm{V}$ \\
\hline Waktu Munculnya Kecambah (hari) & tn & tn & tn \\
Jumlah Kecambah Pada Hari Pertama $(\%)$ & tn & $*$ & tn \\
Waktu Kecambah 50\% (hari) & $* *$ & $* *$ & tn \\
Kecepatan Perkecambahan \% (hari) & tn & tn & tn \\
Daya Berkecambah $(\%)$ & $* *$ & tn & tn \\
Berat Kering Kecambah Normal (gram) & $* *$ & $* *$ & tn \\
Panjang Hipokotil Kecambah Normal $(\mathrm{cm})$ & $*$ & $* *$ & tn \\
Panjang Radikula Kecambah Normal $(\mathrm{cm})$ & tn & tn & tn \\
\hline
\end{tabular}

\begin{tabular}{lll}
\hline Keterangan : & $\mathrm{P}$ & $=$ Priming \\
$\mathrm{V}$ & $=$ Varietas \\
$\mathrm{P} \times \mathrm{V}$ & $=$ Interaksi priming dan varietas \\
$*$ & $=$ Nyata pada $\alpha 5 \%$ \\
$* *$ & $=$ Sangat nyata pada $\alpha 1 \%$ \\
tn & $=$ Tidak nyata
\end{tabular}

Tabel 2. Pengaruh priming terhadap waktu munculnya kecambah dan T50 \% yang dikecambahkan pada tanah ultisol

\begin{tabular}{lcc}
\hline Priming & WMK (hari) & T50 \% (hari) \\
\hline Kontrol & $2.81 \mathrm{ab}$ & $2.97 \mathrm{ab}$ \\
$\mathrm{Air}$ & $3.08 \mathrm{~b}$ & $3.25 \mathrm{~b}$ \\
$\mathrm{KNO}_{3} 1 \%$ & $2.86 \mathrm{ab}$ & $3.03 \mathrm{ab}$ \\
$\mathrm{KNO}_{3} 2 \%$ & $2.93 \mathrm{ab}$ & $3.03 \mathrm{ab}$ \\
$\mathrm{GA}_{3} 50 \mathrm{ppm}$ & $2.52 \mathrm{a}$ & $2.66 \mathrm{a}$ \\
$\mathrm{GA}_{3} 100 \mathrm{ppm}$ & $2.90 \mathrm{ab}$ & $2.78 \mathrm{ab}$ \\
PEG $7.5 \%$ & $2.98 \mathrm{ab}$ & $3.12 \mathrm{ab}$ \\
\hline BNJ 0.05 & 0.53 & 0.47 \\
\hline
\end{tabular}

Keterangan : $\quad$ WMK $=$ Waktu Munculnya Kecambah (hari)

T50 \% = waktu munculnya kecambah sebanyak $50 \%$

Tabel 3. Pengaruh priming terhadap kecepatan perkecambahan, first counting, dan daya berkecambah benih kedelai yang dikecambahkan pada tanah ultisol

\begin{tabular}{lccc}
\hline Priming & Kct $(\% /$ hari $)$ & FC $(\%)$ & DB $(\%)$ \\
\hline Kontrol & $35.91 \mathrm{ab}$ & $39.11 \mathrm{a}$ & $96.89 \mathrm{a}$ \\
$\mathrm{Air}$ & $32.69 \mathrm{~b}$ & $32.89 \mathrm{a}$ & $87.56 \mathrm{~b}$ \\
$\mathrm{KNO}_{3} 1 \%$ & $35.59 \mathrm{ab}$ & $32.89 \mathrm{a}$ & $80.88 \mathrm{bc}$ \\
$\mathrm{KNO}_{3} 2 \%$ & $35.45 \mathrm{ab}$ & $42.22 \mathrm{a}$ & $87.11 \mathrm{~b}$ \\
$\mathrm{GA}_{3} 50 \mathrm{ppm}$ & $40.21 \mathrm{a}$ & $44.00 \mathrm{a}$ & $82.67 \mathrm{bc}$ \\
$\mathrm{GA}_{3} 100 \mathrm{ppm}$ & $34.89 \mathrm{ab}$ & $34.67 \mathrm{a}$ & $80.00 \mathrm{bc}$ \\
PEG $7,5 \%$ & $33.98 \mathrm{ab}$ & $24.44 \mathrm{a}$ & $75.11 \mathrm{c}$ \\
\hline BNJ 0,05 & 6.80 & 33.28 & 9.03 \\
\hline
\end{tabular}

Keterangan : $\quad$ Kct $=$ Kecepatan Perkecambahan (\%/hari)

$\mathrm{FC}=$ First Counting/jumlah kecambah pada hari pertama $(\%)$

$\mathrm{DB}=$ Daya Berkecambah (\%) 
Berdasarkan hasil penelitian perlakuan priming mampu mempercepat waktu munculnya kecambah dan waktu munculnya kecambah sebanyak $50 \quad \%$ apabila dikecambahkan pada tanah ultisol. Priming Giberelin 50 ppm memberikan waktu tercepat pada variabel waktu munculnya kecambah pada hari ke 2.52 dibandingkan priming air yang muncul pada hari ke 3.03. Priming Giberelin 50 ppm juga memberikan waktu tercepat dalam waktu munculnya kecambah sebanyak $50 \%$ yaitu pada hari ke 2.66 dibandingkan priming air yang muncul pada hari ke 3.25 .

Priming lainnya seperti $\mathrm{KNO}_{3} 1 \%$, $\mathrm{KNO}_{3} 2 \%$, Giberelin 100 ppm, dan PEG $7.5 \%$ juga dapat mempercepat waktu perkecambahan benih yang dikecambahakan pada tanah ultisol, walaupun tidak ada perbedaan diantara perlakuan priming tersebut (Tabel 2). Kemampuan priming Giberelin dalam meningkatkan waktu munculnya kecambah dan T50 \% sejalan dengan penelitian (Ghobadi et al., 2012) pada tanaman gandum, tanaman kedelai (Langeroodi \& Noora, 2017), cabai (Ulya et al., 2020). Hal ini dikarenakan Giberelin merupakan hormon tumbuh yang berperan penting dalam proses perkecambahan, karena dapat mengaktifkan reaksi enzimatik di dalam benih (Bey et al., 2005).

Priming air memiliki waktu muncul kecambah dan T50 \% terendah dikarenakan kadar air benih yang tinggi dapat meningkatkan laju kemunduran benih pada tempat penyimpanan. Laju kemunduran benih dapat diperlambat dengan cara kadar air benih harus dikurangi sampai kadar air benih optimum (Tuwu et al., 2012). Kadar air benih yang melebihi batas kritikalnya akan menyebabkan kerusakan protein, diduga terbentuknya radikal bebas.

Hasil penelitian menyatakan bahwa priming Giberelin 50 ppm memiliki nilai kecepatan perkecambahan yaitu $40.21 \%$ /hari dibandingkan priming air yaitu sebesar $32.69 \%$ /hari, sedangkan perlakuan priming lainnya seperti $\mathrm{KNO}_{3} 1 \%, \mathrm{KNO}_{3}$
$2 \%$, Giberelin 100 ppm, dan PEG $7.5 \%$ dan juga dapat meningkatkan kecepatan perkecambahan walaupun tidak berbeda diantara priming tersebut. Perlakuan priming ataupun kontrol tidak memiliki perbedaan pada variabel jumlah radikula yang muncul pada hari pertama, tetapi nilai tertingginya berada pada priming Giberelin 50 ppm sebesar $44.00 \%$.

Variabel pengamatan jumlah kecambah yang muncul pada hari pertama tidak memiliki perbedaan pada tiap perlakuan priming maupun kontrol. Dengan nilai tertingginya Giberelin $50 \mathrm{ppm}$ yaitu 44,00 \% dibandingkan priming PEG $7.5 \%$ yaitu $24.44 \%$. Daya berkecambah tertinggi didapatkan oleh perlakuan kontrol sebesar $96.89 \%$, priming air dan $\mathrm{KNO}_{3} 2 \%$ juga dapat meningkatkan daya berkecambah dengan nilai DB $87.56 \%$ dan $87.11 \%$. (Tabel 3).

Priming Giberelin terbaik dalam kecepatan perkecambahan sejalan dengan waktu munculnya kecambah dan T50 \%, hal ini dikarenakan apabila waktu munculnya kecambah cepat maka kecepatan perkecambahan setiap harinya juga akan meningkat (Tabel 2). Daya berkecambah perlakuan kontrol tertinggi dibandingkan perlakuan lain, dikarenakan benih kedelai yang digunakan adalah benih baru, sehingga daya berkecambahnya masih tinggi. Untuk melihat perbedaannya diamati pada variabel lain, seperti waktu munculnya kecambah ataupun kecepatan perkecambahan per harinya.

Hasil penelitian menyatakan bahwa perlakuan kontrol memiliki nilai berat kering kecambah normal terbaik yaitu $5.67 \mathrm{~g}$, sedangkan priming air, $\mathrm{KNO}_{3} 1 \%$, Giberelin 50 ppm, Giberelin 100 ppm, dan PEG $7.5 \%$ tidak ada perbedaan diantara priming tersebut. Variabel panjang hipokotil kecambah normal terbaik juga pada perlakuan kontrol yaitu $21.99 \mathrm{~cm}$ dibandingkan priming $\mathrm{KNO}_{3} \quad 1 \%$ yaitu $18.05 \mathrm{~cm}$. Variabel panjang radikula kecambah normal tidak terdapat perbedaan diantara perlakuan priming ataupun kontrol, 
dengan panjang radikula tertinggi yaitu priming Giberelin $12.02 \mathrm{~cm}$ (Tabel 4).

Bobot kering kecambah normal dan panjang hipokotil kecambah normal tertinggi adalah perlakuan kontrol dikarenakan benih kedelai yang digunakan pada penelitian ini adalah benih kedelai baru. Sehingga akan tetap berkecambah dan yang membedakannya adalah variabel lain seperti kecepatan perkecambahan dan waktu munculnya kecambah.

Giberelin $\left(\mathrm{GA}_{3}\right)$ memainkan peran penting dalam banyak aspek pertumbuhan dan perkembangan tanaman, seperti perkecambahan biji, perpanjangan batang, akar dan perkembangan bunga (Leite et al., 2003). Oleh karena itu, Giberelin berperan penting dalam meningkatkan panjang radikula kecambah. Hal ini sejalan dengan penelitian (Miladinov et al., 2018) pada tanaman kedelai, tanaman jagung (Supardy et al., 2016), dan mentimun (Anwar et al., 2020).

Benih kedelai varietas Anjasmoro, Burangrang, dan Grobogan pada waktu munculnya kecambah tidak terdapat perbedaan antar varietasnya, dengan nilai tertinggi benih Burangrang yaitu 2.75 hari. Pada variabel waktu munculnya kecambah sebanyak $50 \%$ bahwa benih Burangrang memiliki nilai T50 \% sebesar 2.77 hari dibandingkan benih Grobogan sebesar 3.16 hari (Tabel 5).

Tabel 4. Pengaruh priming terhadap bobot kering kecambah normal, panjang hipokotil kecambah normal, dan panjang radikula kecambah normal yang dikecambahkan pada tanah ultisol

\begin{tabular}{lccc}
\hline Priming & BKKN $(\mathrm{g})$ & PHKN $(\mathrm{cm})$ & PRKN $(\mathrm{cm})$ \\
\hline Kontrol & $5.67 \mathrm{a}$ & $21.99 \mathrm{a}$ & $11.63 \mathrm{a}$ \\
Air & $4.10 \mathrm{~b}$ & $19.45 \mathrm{ab}$ & $11.66 \mathrm{a}$ \\
$\mathrm{KNO}_{3} 1 \%$ & $4.02 \mathrm{~b}$ & $18.05 \mathrm{~b}$ & $11.17 \mathrm{a}$ \\
$\mathrm{KNO}_{3} 2 \%$ & $4.45 \mathrm{ab}$ & $20.54 \mathrm{ab}$ & $1146 \mathrm{a}$ \\
$\mathrm{GA}_{3} 50 \mathrm{ppm}$ & $3.92 \mathrm{~b}$ & $18.72 \mathrm{ab}$ & $12.02 \mathrm{a}$ \\
$\mathrm{GA}_{3} 100 \mathrm{ppm}$ & $3.52 \mathrm{~b}$ & $19.33 \mathrm{ab}$ & $10.36 \mathrm{a}$ \\
PEG 7,5 \% & $3.37 \mathrm{~b}$ & $18.79 \mathrm{ab}$ & $10.07 \mathrm{a}$ \\
\hline BNJ 0,05 & 1.26 & 3.5 & 2.81 \\
\hline Keterangan: & BKKN = Bobot Kering Kecambah Normal $(\mathrm{g})$ & \\
& PHKN = Panjang Hipokotil Kecambah Normal $(\mathrm{cm})$ &
\end{tabular}

Tabel 5. Pengaruh varietas terhadap waktu munculnya kecambah dan T50 \% yang dikecambahkan pada tanah ultisol

\begin{tabular}{lcc}
\hline \multicolumn{1}{c}{ Varietas } & WMK (hari) & T50\% (hari) \\
\hline Anjasmoro & $2.89 \mathrm{a}$ & $3.01 \mathrm{ab}$ \\
Burangrang & $2.75 \mathrm{a}$ & $2.77 \mathrm{a}$ \\
Grobogan & $2.96 \mathrm{a}$ & $3.16 \mathrm{~b}$ \\
\hline BNJ 0,05 & 0.27 & 0.24 \\
\hline
\end{tabular}

Keterangan: $\quad$ WMK $=$ Waktu Munculnya Kecambah (hari)

$\mathrm{T} 50 \%$ = waktu munculnya kecambah sebanyak $50 \%$ 
Benih kedelai varietas Grobogan dan Burangrang memiliki waktu muncul dan $\mathrm{T} 50 \%$ tercepat dikarenakan menurut Balitkabi (2016) kedua benih tersebut masuk dalam benih besar, sehingga radikula akan lebih cepat muncul kepermukaan tanah. Oleh karena itu, waktu kecambahnya akan lebih capat daripada benih kedelai varitetas Anjasmoro.

Berdasarkan hasil penelitian didapatkan bahwa tidak ada perbedaan pada benih varietas Anjasmoro, Burangrang dan Grobogan pada variabel kecepatan perkecambahan dan daya berkecambah. Nilai terbaik pada benih varietas Burangrang yaitu kecepatan perkecambahan $36.88 \% /$ hari dan daya berkecambah $86.67 \%$. Sedangkan pada variabel waktu munculnya kecambah pada hari pertama nilai terbaik juga dimiliki oleh benih varietas Burangrang yaitu $48.38 \%$ dibandingkan Anjasmoro $30.48 \%$ dan Grobogan $28.38 \%$ (Tabel 6).

Benih kedelai varietas Burangrang adalah varietas terbaik yang dapat meningkatkan kecepatan perkecambahan (\%/hari), jumlah kecambah yang muncul pada hari pertama (\%), dan daya berkecambah (\%). Dikarenakan menurut Warid et al. (2016) benih Burangrang memiliki sifat agak toleran terhadap lahan kering, contohnya tanah ultisol.

Tabel 6. Pengaruh varietas terhadap kecepatan perkecambahan, first counting, dan daya berkecambah benih yang dikecambahkan pada tanah ultisol

\begin{tabular}{lccc}
\hline \multicolumn{1}{c}{ Varietas } & Kct (\%/hari) & FC (\%) & DB (\%) \\
\hline Anjasmoro & $35.32 \mathrm{a}$ & $30.48 \mathrm{~b}$ & $83.24 \mathrm{a}$ \\
Burangrang & $36.88 \mathrm{a}$ & $48.38 \mathrm{a}$ & $86.67 \mathrm{a}$ \\
Grobogan & $34.40 \mathrm{a}$ & $28.38 \mathrm{~b}$ & $83.05 \mathrm{a}$ \\
\hline BNJ 0,05 & 3.49 & 17.09 & 4.64 \\
\hline
\end{tabular}

Keterangan : $\quad$ Kct $=$ Kecepatan Perkecambahan (\%/hari)

$\mathrm{FC}=$ First Counting/jumlah kecambah pada hari pertama $(\%)$

$\mathrm{DB}=$ Daya Berkecambah $(\%)$

Tabel 7. Pengaruh varietas terhadap bobot kering kecambah normal, panjang hipokotil kecambah normal, dan panjang radikula kecambah normal yang dikecambahkan pada tanah ultisol

\begin{tabular}{lccc}
\hline \multicolumn{1}{c}{ Varietas } & BKKN $(\mathrm{g})$ & PHKN $(\mathrm{cm})$ & PRKN $(\mathrm{cm})$ \\
\hline Anjasmoro & $4.49 \mathrm{a}$ & $21.36 \mathrm{a}$ & $11.08 \mathrm{a}$ \\
Burangrang & $4.28 \mathrm{ab}$ & $18.79 \mathrm{~b}$ & $11.83 \mathrm{a}$ \\
Grobogan & $3.66 \mathrm{~b}$ & $18.52 \mathrm{~b}$ & $10.67 \mathrm{a}$ \\
\hline BNJ 0,05 & 0.64 & 1.8 & 1.44 \\
\hline Keterangan: & BKKN = Bobot Kering Kecambah Normal $(\mathrm{g})$ & \\
& PHKN $=$ Panjang Hipokotil Kecambah Normal $(\mathrm{cm})$ & \\
& PRKN $=$ Panjang Radikula Kecambah Normal $(\mathrm{cm})$ &
\end{tabular}

Benih varietas Anjasmoro memiliki nilai berat kering kecambah normal sebesar $4.49 \mathrm{~g}$ dibandingkan benih Grobogan yaitu sebesar 3.66 g. Panjang hipokotil kecambah normal juga terbaik pada benih Anjasmoro yaitu sebesar $21.36 \mathrm{~cm}$ dibandingkan Burangrang dan Grobogan yaitu sebesar $18.79 \mathrm{~cm}$ dan $18.52 \mathrm{~cm}$. Pada variabel panjang radikula kecambah normal tidak terdapat perbedaan diantara varietasnya 
Anjasmoro, Burangrang, ataupun Grobogan (Tabel 7).

Benih kedelai varietas Anjasmoro memiliki nilai berat kering kecambah normal dan panjang hipokotil kecambah normal tertinggi dikarenakan menurut Warid et al. (2016) benih Anjasmoro memiliki sifat agak toleran terhadap kekeringan, yaitu tanah ultisol yang digunakan pada penelitian ini. Sehingga akan mampu mempertahankan nilai berat kering dan panjang hipokotil dibandingakan benih Burangrang dan Grobogan. Panjang radikula kecambah normal terbaik berada pada benih Burangrang dikarenakan benih tersebut juga memiliki sifat agak toleran terhadap kekeringan dibandingkan benih Grobogan yang hanya peka terhadap kekeringan (Warid et al., 2016).

\section{KESIMPULAN}

Berdasarkan hasil penelitian dan pembahasan, ditarik kesimpulan sebagai berikut:

(1) Priming Giberelin 50 ppm merupakan priming terbaik dalam variabel waktu munculnya kecambah (hari), T50 \% , dan kecepatan perkecambahan yang dikecambahkan pada tanah ultisol.

(2) Benih kedelai varietas Burangrang terbaik dalam variabel T50 \% dan jumlah radikula yang muncul pada hari pertama. Benih kedelai varietas Anjasmoro terbaik dalam variabel berat kering kecambah normal dan panjang hipokotil kecambah normal yang dikecambahkan pada tanah ultisol.

\section{DAFTAR PUSTAKA}

Anwar, A., Yu, X., \& Li, Y. (2020). Seed priming as a promising technique to improve growth, chlorophyll, photosynthesis and nutrient contents in cucumber seedlings. Notulae Botanicae Horti Agrobotanici Cluj-Napoca, 48(1), 116-127.
https://doi.org/10.15835/NBHA4811180 6.

Badan Statistika Pusat. (2018). Produktivitas Kedelai. BPS. Jakarta.

Balitkabi. (2016). Deskripsi Varietas Unggul Kedelai 1918-2016. Badan litbang. Puslitbangtan. Balitkabi Malang.

Bey, Y., Syafii, W., \& Ngafifah, N. (2005). Pengaruh Pemberian Giberelin Pada Media Vacin Dan Went Terhadap Perkecambahan Biji Anggrek Bulan (Phalaenopsis amabilis BI) Secara In Vitro. Jurnal Biogenesis, 1(2), 57-61.

Ernita dan F. Mairizki. (2019). Teknik Invigorasi Untuk Memperbaiki. Jurnal Ilmiah Pertanian, 16(1), 8-18.

Ghobadi, M., Shafiei Abnavi, M., Honarmand, S. J., Ghobadi, M. E., \& Reza Mohammadi, G. (2012). Effect of Hormonal Priming (GA3) and Osmopriming on Behavior of Seed Germination in Wheat (Triticum aestivum L.). Journal of Agricultural Science, 4(9), 244-250. https://doi.org/10.5539/jas.v4n9p244.

Jocković, M., Čanak, P., Miklič, V., Ovuka, J., Radić, V., Jocić, S., Cvejić, S., \& Marjanović-Jeromela, A. (2018). Effect of Seed Priming Techniques on Germination Parameters of Safflower ( Carthamus tinctorius L.) . Contemporary Agriculture, 67(2), 157-163. https://doi.org/10.2478/contagri-20180022.

Kochian, L. V., Hoekenga, O. A., \& Piñeros, M. A. (2004). How do crop plants tolerate acid soils? Mechanisms of aluminum tolerance and phosphorous efficiency. Annual Review of Plant Biology, 55, 459493.

https://doi.org/10.1146/annurev.arplant.5 5.031903.141655.

Langeroodi, A. R. S., \& Noora, R. (2017). Seed priming improves the germination and field performance of soybean under drought stress. Journal of Animal and Plant Sciences, 27(5), 1611-1620.

Leite, V. M., Rosolem, C. A., \& Rodrigues, J. D. (2003). Gibberellin and cytokinin effects 
on soybean growth. Scientia Agricola, 60(3), 537-541.

https://doi.org/10.1590/s0103-

90162003000300019.

Miladinov, Z., Balešević-Tubić, S., Đukić, V., Ilić, A., Čobanović, L., Dozet, G., \& Merkulov-Popadić, L. (2018). Effect of priming on soybean seed germination parameters. Acta Agriculturae Serbica, 23(45), 15-26. https://doi.org/10.5937/aaser1845015m.

Milatuzzahroh, L., Ridlo, S., \& Anggraito, U. (2019). Pengaruh Berbagai Konsentrasi dan Lama Cekaman Aluminium terhadap Pertumbuhan Akar Kemampuan Root regrowth Stek Batang Hydrangea macrophylla pada Kultur Cair. Life Science, 8(1), 96-105.

Nawaz, J., Hussain, M., Jabbar, A., Nadeem, G. A., Sajid, M., Subtain, M., \& Shabbir, I. (2013). Seed Priming A Technique. International Journal of Agriculture and Crop Sciences, 6(20), 1373-1381.

Prasetyo, A. W., \& , Arifin Noor Sugiharto, B. G. (2019). Pengaruh Pemberian Berbagai Macam Bahan Priming terhadap Pertunbuhan dan Hasil Benih Jagung Manis ( Zea mays L . saccharata Sturt .) Jurnal Produksti Tanaman. 7(7), 11981205.

Prasetyo, B., \& Suriadikarta, D. (2006). Karakteristik, Potensi, dan Teknologi Pengelolaan Tanah Ultisol untuk Pengembangan Pertanian Lahan Kering di Indonesia. Jurnal Litbang Pertanian, 25(2), 39-47. http://pustaka.litbang.deptan.go.id/publik asi/p3252061.pdf.

Putra, F. O. P., \& Kurnia, T. D. (2019). Pemaraman Benih Gandum (Triticum aestivum L .) untuk Meningkatkan Kualitas Perkecambahan pada Kondisi Cekaman Kering. Jurnal Agric, 31(1), 89101.

Singh, D., \& Laxmi, A. (2015). Transcriptional regulation of drought response: A tortuous network of transcriptional factors. Frontiers in Plant Science, 6, 1-11. https://doi.org/10.3389/fpls.2015.00895

Supardy, Adelina, E., \& Made, U. (2016). Pengaruh lama perendaman dan konsentrasi Giberelin ( GA 3 ) terhadap viabilitas benih kakao ( Theobroma cacao L . ). E-J. Agrotekbis, 2(3), 425-431. https://media.neliti.com/media/publicatio ns/244882-none-26dae8a4.pdf

Supriatin, Sarno, J. Lumbanraja dan Dermiyati. (2017). Penetapan Sample Tanah Standar Untuk Menjamin Mutu ( Quality Kontrol ) Hasil Analisis Sample Tanah Laboratorium Ilmu Tanah Universitas Lampung. Laporan Penelitian Jurusan Ilmu Tanah Universitas Lampung. Bandar Lampung.

Tuwu, E.R., Sutariati, G.A.K., dan Suaib. (2012). Pengaruh Kadar Air Benih dan Jenis Kemasan Terhadap Vigor Benih Sorgum ( Sorghum bicolor ( $\mathrm{L}$.) Moench ) Dalam Enam Bulan MAsa SImpan. Penelitian Agronomi. 1(2), 184193.

Ulya, P. D., W. Slamet, \& Karno. (2020). Pertumbuhan dan hasil tanaman cabai keriting (Capsicum annum 1.) pada konsentrasi dan lama perendaman giberelin yang berbeda. Jurnal Agro Complex, 4(1), 23-31.

Warid, Khumaida, N., Purwito, A., Syukur, M., dan Aardie, W. (2016). Penapisan cepat beberapa varietas kedelai terhadap cekaman kekeringan pada fase perkecambahan. Seminar Nasional Perhoti dan Peragi. Universitas Hasanuddin. 